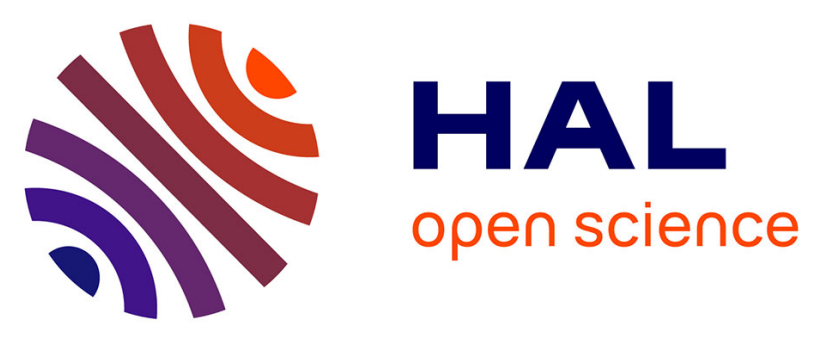

\title{
Common genetic variation of insulin-like growth factor-binding protein 1 (IGFBP-1), IGFBP-3, and acid labile subunit in relation to serum IGF-I levels and mammographic density
}

Cornelia W. Taverne, Martijn Verheus, James D. Mckay, Rudolf Kaaks, Federico Canzian, Diederick E. Grobbee, Petra H. M. Peeters, Carla H. Gils

\section{To cite this version:}

Cornelia W. Taverne, Martijn Verheus, James D. Mckay, Rudolf Kaaks, Federico Canzian, et al.. Common genetic variation of insulin-like growth factor-binding protein 1 (IGFBP-1), IGFBP-3, and acid labile subunit in relation to serum IGF-I levels and mammographic density. Breast Cancer Research and Treatment, 2010, 123 (3), pp.843-855. 10.1007/s10549-010-0778-2 . hal-00520005

\section{HAL Id: hal-00520005 https://hal.science/hal-00520005}

Submitted on 22 Sep 2010

HAL is a multi-disciplinary open access archive for the deposit and dissemination of scientific research documents, whether they are published or not. The documents may come from teaching and research institutions in France or abroad, or from public or private research centers.
L'archive ouverte pluridisciplinaire HAL, est destinée au dépôt et à la diffusion de documents scientifiques de niveau recherche, publiés ou non, émanant des établissements d'enseignement et de recherche français ou étrangers, des laboratoires publics ou privés. 
Common genetic variation of Insulin-like Growth Factor-binding Protein 1 (IGFBP-1), IGFBP-3, and Acid Labile Subunit in relation to serum IGF-I levels and mammographic density

Cornelia W. Taverne ${ }^{1}$, Martijn Verheus ${ }^{1,2}$, James D. McKay ${ }^{3}$, Rudolf Kaaks ${ }^{4}$, Federico Canzian ${ }^{4}$, Diederick E. Grobbee ${ }^{1}$, Petra H.M. Peeters ${ }^{1,6}$, Carla H. van Gils ${ }^{1}$

${ }^{1}$ Julius Center for Health Sciences and Primary Care, University Medical Center, Utrecht, the Netherlands

${ }^{2}$ Department of Epidemiology, Netherlands Cancer Institute, Amsterdam, The Netherlands

${ }^{3}$ Genetic Epidemiology Group, International Agency for Research on Cancer (IARC-WHO), Lyon, France

${ }^{4}$ Division of Cancer Epidemiology, German Cancer Research Center (DKFZ), Heidelberg, Germany

${ }^{5}$ Genomic Epidemiology Group, German Cancer Research Center (DKFZ), Heidelberg, Germany

${ }^{6}$ Department of Epidemiology and Public Health, Faculty of Medicine, Imperial College, London, United Kingdom

Corresponding author: Carla H. van Gils, $\mathrm{PhD}$, Julius Center of Health Sciences and Primary Care, Room Str 6.131, PO Box 85500, University Medical Center, Utrecht 3508 GA Utrecht, the Netherlands (C.vanGils@umcutrecht.nl)

Keywords: mammographic density, IGF-I levels, single nucleotide polymorphism, ALS, IGFBP1, IGFBP3, Prospect-EPIC 


\begin{abstract}
Background: Mammographic density is strongly related to increased breast cancer risk. Accumulating evidence indicates a role for the IGF-pathway in mammographic density and breast cancer development. Here we investigate whether common genetic variation in this pathway influences IGF-I levels and mammographic density
\end{abstract}

Methods: In 1916 premenopausal women within the Prospect-EPIC cohort we examined associations of 14 haplotype tagging SNPs in the ALS, IGFBP1 and IGFBP3 genes with IGF-I circulating levels and mammographic density. In 657 women who became postmenopausal during follow-up we investigated how these SNPs were related with the decrease in density over menopause. Linear regression models were used for statistical analysis.

Results: None of the ALS or IGFBP3 SNPs were statistically significantly associated with IGF-I levels or mammographic density. The CC genotype for rs1908751 (IGFBP1) was associated with lower levels of IGF-I $(110.9 \mathrm{ng} / \mathrm{mL})$ compared to the CT/TT genotypes $(115.7 \mathrm{ng} / \mathrm{mL})(\mathrm{p}=0.04)$. Women with the CC genotype also had lower percent density, although not statistically significantly ( $\mathrm{p}=0.12$ ). Women carrying the AA genotype for rs1995051 (IGFBP1) showed borderline significantly lower IGF-I levels ( $\mathrm{p}=0.06$ ) and significantly lower mammographic density (40.3\% compared to $43.5 \%$ in the $\mathrm{GG} / \mathrm{GA}$ genotypes $(\mathrm{p}=0.05)$ ). No relationships were found for any of the SNPs in relation to changes in breast density over menopause.

Conclusion: These findings suggest that common genetic variation in the IGFBP1 gene is weakly related to IGF-I levels and mammographic density. Our results do not provide support for such a role of genetic variants in the IGFBP3 and ALS genes. 


\section{Introduction}

One of the strongest risk factors for breast cancer is high mammographic density [1]. Mammographic density represents the amount of stromal and glandular tissue in the breast as compared to fat [2]. Women with a high proportion of mammographically dense tissue have four to six-fold higher breast cancer risk compared to women with low mammographic density [3]. Factors that influence mammographic density might therefore also affect breast cancer risk.

Insulin-like growth factor-I (IGF-I) is known to be involved in normal breast tissue development [4]. In research with breast cancer cell lines, IGF-I has proved to be a potent mitogen and an inhibitor of apoptosis [5, 6]. It has been suggested that elevated levels of IGF-I may increase breast density and thereby increase the risk of breast cancer. Several studies have shown that elevated circulating levels of IGF-I are directly associated with higher mammographic density in premenopausal women [7-10], although these findings were not confirmed in all studies [11-13]. The association of circulating IGF-I levels with mammographic density was not seen in postmenopausal women [7-9, 11, 12].

The major part of circulating IGF-I is bound to IGF-binding proteins (IGFBPs). Seven IGFBPs have been characterised (IGFBP1-7) and are involved in the regulation of IGF-I. Inhibitory as well as potentiating effects of IGFBP-1 on the action of IGF-I have been shown in vitro (reviewed by Jones et al. [14]). In the blood system, about $90 \%$ of IGF-I is bound to IGFBP-3. Together with a small glycoprotein called acid labile subunit (ALS), IGF-I and IGFBP-3 form a 150-kDa ternary complex inhibiting IGF-I to exert its biological actions [14, 15]. IGFBP-3 has also been shown to act independently from IGF-I by inducing apoptosis $[16,17]$. High circulating levels of IGFBP-3 have been shown to be related to lower mammographic density in premenopausal women [7-9], but not all studies confirm this $[10,12]$. In postmenopausal women no relation was found between IGFBP-3 levels and mammographic density [7-9].

Circulating levels of IGF-I and its binding proteins fluctuate over time. Genetic polymorphisms are stable during life and offer another possibility to study the relationship between the IGF system and mammographic density. Several studies examined the influence of polymorphisms in the IGF-I gene on circulating levels of IGF-I [18-22] and mammographic density [12, 23]. Some studies also investigated the relation between polymorphisms in the genes of IGFBP1 and IGFBP3 and mammographic density [11, 12, 23].

We conducted a study of 1916 premenopausal women within the Prospect-European Prospective Investigation into Cancer and Nutrition (EPIC) cohort to examine the cross-sectional association of 14 haplotype tagging single nucleotide polymorphisms (htSNPs) in the IGFBP1, IGFBP3 and ALS genes with circulating IGF-I levels and in relation to mammographic density. In an additional longitudinal part of the study we studied changes in mammographic density in a subgroup of women who became postmenopausal during approximately 5.4 years of follow-up. We examined whether mammographic density decreased to a smaller extent in women with specific polymorphisms in the ALS, IGFBP1 and IGFBP3 genes. 


\section{Materials and methods}

\section{Study population}

Women included in this study are participants of the Prospect cohort, which is part of the larger ongoing European Prospective Investigation into Cancer and Nutrition (EPIC). EPIC is a multicenter cohort study within ten European countries. The design and details of the EPIC study are described elsewhere [24]. The Prospect-EPIC study population consists of 17,357 women living in Utrecht (Netherlands) and its vicinity, who were enrolled in the study between 1993 and 1997. These women were recruited through a regional screening programme for breast cancer. Once every two years mammographic examinations are done as part of this screening programme.

At time of study enrolment women were 49-69 years of age. At enrolment, demographic, reproductive, and lifestyle factors as well as past and current morbidity were collected using a questionnaire and additionally a blood sample was taken. Further details of the Prospect study are described by Boker et al. [25]. Approximately 3 to 5 years after baseline measurements, a follow-up questionnaire on past and current morbidity, reproductive and lifestyle factors was filled out by the participants.

All participants signed an informed consent and the study was approved by the Institutional Review Board of the University Medical Center Utrecht.

\section{Selection of study subjects}

From the total study population 16,917 women had donated a blood sample. Of this group 4,055 women were still pre- or perimenopausal (defined as having had at least one menses in the past 12 months) at time of recruitment. Women were excluded when having had ovariectomy on both ovaries. Use of oral contraceptives (OC) or hormone replacement therapy (HRT) has been shown to influence mammographic density. Therefore, women who were using OC or HRT at the time of recruitment and former users who stopped less than two years earlier were not included in this study. Two hundred and sixty-four women had to be excluded because their mammograms could not be retrieved from the archives. Fourteen women having silicone protheses were excluded, because this hampers the assessment of mammographic density. Twenty-two women had too large breasts to fit on a single mammogram and were therefore excluded. Another 44 women were excluded, because a blood sample could not be retrieved from the Prospect-EPIC biobank. Finally, we excluded 65 women for whom less than 9 of the 14 SNPs could be genotyped. This resulted in 1916 pre- and perimenopausal women who were included in the analyses.

Seven hundred and fifty of these women became postmenopausal (defined as not having had any menses in the past 12 months) after recruitment, but before filling out the follow-up questionnaire 
which was on average 4.4 years later. For 657 of them we had complete genetic data, pre- and postmenopausal mammograms, and serum samples to use for IGF-I measurements.

\section{Blood sample collection}

A 30-mL nonfasting blood sample was donated by each participant at enrolment using three safety monovettes: one dry monovette for serum and two citrated monovettes for plasma. Within $24 \mathrm{~h}$, samples of $4 \mathrm{~mL}$ serum, $9 \mathrm{~mL}$ citrate plasma, and $2 \mathrm{~mL}$ white blood cells were fractionated into 0.5 $\mathrm{mL}$ aliquots and stored in heat-sealed plastic straws under liquid nitrogen at $-196^{\circ} \mathrm{C}$.

\section{Selection and genotyping of SNPS}

We identified regions with limited haplotype diversity, i.e. haplotype blocks, across the IGFBP1, IGFBP 3 and ALS genes by obtaining genotype data for 30 Caucasian CEPH trios from the HapMap phase II database (http://www.hapmap.org [26]), covering and including $10 \mathrm{~kb}$ upstream and $5 \mathrm{~kb}$ downstream using the Haploview software [27]. The minimum number of SNPs required to uniquely identify all common haplotypes in the haplotype blocks were selected as "haplotype tagging SNPs". For the IGFBP1 gene six tagging SNPs were selected, for the IGFBP3 gene and the ALS gene these numbers are five and three, respectively. Information on SNPs, including rs numbers and minor allele frequencies, are presented in Table 1.

Genotyping of our study population was performed by the 5' nuclease assay (Taqman). Taqman probes were synthesised by either Applied Biosystems (with MGB chemistry) or Proligo (with or without LNA chemistry). The reaction mix included 10 ng genomic DNA, 5 pmol of each primer, 1 pmol of each probe, and $2.5 \mu \mathrm{L}$ of $2 \mathrm{X}$ master mix (Applied Biosystems) in a final volume of $5 \mu \mathrm{L}$. The thermocycling included 50 cycles with 30 seconds at $95^{\circ} \mathrm{C}$ followed by 60 seconds at $60^{\circ} \mathrm{C}$. PCR plates were read on an ABI PRISM 7900HT instrument (Applied Biosystems). The distributions of genotypes of all polymorphisms were in agreement with the Hardy-Weinberg equilibrium. Repeated quality control genotypes ( $8 \%$ of total) showed greater than $99 \%$ concordance for all assays.

\section{IGF-I measurements}

IGF-I concentrations in serum were measured in the blood samples taken at enrolment and only in the subgroup of women $(n=657)$ who went through menopause shortly after recruitment [13]. Analyses were performed by Labor Benrath (Düsseldorf, Germany) using Immulite 2000 technology with reagents from Diagnostic Products Corp. (Frankfurt, Germany) in 11 batches, each of which contained the same two control samples. The interbatch coefficients of variation for the two control samples were $3.73 \%$ and $2.62 \%$, respectively.

\section{Mammographic density analysis}


Mammographic density was assessed as previously described [13]. In brief, the mediolateral oblique mammogram -which is the routine view for breast cancer screening in the Netherlands- of the left breast was used. Films were digitised using a laser film scanner (Lumiscan 50, Lumisys, Eastman Kodak Co., Rochester, NY). The total area of the breast on the digitized mammogram as well as the area of dense breast tissue was determined using a computer-assisted method based on grey levels of pixels in the digitized mammogram [28]. Percentage density was computed by dividing the absolute dense area by the total breast area, multiplied by 100 .

One observer assessed all mammograms in sets of 36 images. Pre- and a postmenopausal mammograms of the same woman were always presented in the same batch in random order. To assess the reliability of the reader, a library set was created, which consisted of 36 randomly chosen films from the study subjects. This library set was read before the first set and at five time points between sets, which were blinded for the reader. Within every assessment of the library set, images were randomised, preventing recognition of the set by the observer. In this study, an average intraclass correlation coefficient of 0.99 (range: 0.99-1.00) for total breast area, 0.81 (range: 0.75-0.86) for absolute dense area, and 0.90 (range: $0.88-0.92$ ) for percentage breast density was reached between repeated readings [13].

\section{Data analysis}

Outcome variables were square root transformed when not normally distributed. This was the case for: IGF-I serum levels, premenopausal dense area and non-dense area as well as postmenopausal dense area, non-dense area, and percentage breast density. Means and 95\% confidence intervals presented in the tables were transformed to the original scale.

To investigate the association between genotypes and circulating levels of IGF-I, linear regression models were used. Differences in mean circulating IGF-I levels between genotypes were evaluated for three different modes of inheritance: dominant, recessive and additive. In the dominant model circulating levels of IGF-I were compared between subjects who were heterozygous or homozygous for the minor allele and those who were homozygous for the major allele. Circulating IGF-I levels of subjects homozygous for the minor allele were compared to the circulating levels of all other subjects in the recessive model. In the additive model circulating IGF-I levels were assumed to be linearly related to the number of copies of the allele, i.e. 0,1 or 2 . For all modes of inheritance pvalues for differences in mean IGF-I levels between genotypes were calculated and presented. When the subgroup of women who were homozygous for the minor allele comprised less than 20 women, they were grouped together with the heterozygous women to gain power. For these SNPs only the dominant mode was assessed.

The genotypes were also investigated for the association with premenopausal dense breast area, non-dense breast area and percentage breast density as well as changes herein over menopause. For these analyses linear regression models were used. Changes in breast measures over menopause were 
calculated as the absolute difference between post- and premenopausal breast measurements. In the models used to analyse changes in breast measures over menopause, premenopausal breast measures were included as covariate. P-values for differences in mean breast values between genotypes were calculated for three modes of inheritance as described for the analyses with IGF-I levels.

In principle, effects of genetic variation on disease outcomes are not likely to be influenced by confounders. However, it is known that BMI is strongly positively associated with the non-dense area of the breast [29]. A relationship between genes in the IGF-pathway and BMI (reviewed by Renehan et al. [30]) may thus lead to the observation of an effect of these genes on percent density, while not actually influencing the dense area, but only the non-dense area. Therefore we include BMI as a possible confounder (continuous variable) in analyses of the relation between IGFBPs and percent density and the non-dense area of the breast. In the premenopausal models BMI at baseline was included. In the models studying changes over menopause, BMI at baseline as well as change in BMI over menopause were included as covariates.

The problem of multiple testing was evaluated using the calculation of a false positive report probability (FPRP), a method reported by Wacholder et al. [31]. In short, with this Bayesian approach one calculates the probability that a finding is not true based on the significance level, the statistical power, and the prior probability of a true association. A finding was considered noteworthy if the FPRP was 0.5 or less.

All p-values are presented as two-sided tests, with a statistical significance level of 0.05 . The statistical analyses were done using the SPSS 14.0 for Windows software package. 


\section{Results}

Table 1 describes the haplotype tagging SNPs used in this study. Baseline characteristics of the study population as well as the subgroup of women who became postmenopausal during follow-up are represented in Table 2.

The median breast values of all premenopausal measures in the subgroup of women who became postmenopausal during follow-up were slightly lower than the breast values of the total study population (Table 3). The dense area of the breast decreased with a median value of $11.9 \mathrm{~cm} 2$ in women during follow-up. The non-dense area increased slightly over menopause $(0.5 \mathrm{~cm} 2)$. Changes in dense- and non-dense area resulted in a decrease in percentage breast density of $6.7 \%$.

For the current study population the association between circulating IGF-I levels and mammographic density has been previously described by Verheus et al[13]. In this study, women with higher premenopausal IGF-I levels showed a higher percent breast density after menopause than women with low IGF-I levels. Associations between SNPs in IGFBP genes and mean IGF-I serum levels are presented in Table 4. None of the SNPs on the genes for ALS or IGFBP3 showed a statistically significant association with circulating IGF-I levels. Overall, however, women who are homozygous for the minor alleles in both the ALS and IGFBP3 genes showed lower IGF-I levels and some of these associations were statistically borderline significant ( $r s 17559, \mathrm{p}=0.08 ; \mathrm{rs} 3751893, \mathrm{p}=0.07$ and rs2854744, p=0.08). Rs1908751 in the IGFBP1 gene was statistically significantly associated with IGF-I levels via the dominant mode of inheritance $(\mathrm{p}=0.04)$. Women carrying the CC genotype showed lower levels of IGF-I (110.9 ng/mL) compared to the combined group of women who are heterozygous ( $\mathrm{n}=249)$ or homozygous $(\mathrm{n}=45)$ for the $\mathrm{T}$ allele $(115.7 \mathrm{ng} / \mathrm{mL})$. It should, however, be noted that the mean IGF-I level in the small group of women with the TT genotype was lower compared to the heterozygotes. Women carrying the AA genotype for rs1995051 showed borderline significant lower IGF-I levels than women with the GG and GA genotypes ( $\mathrm{p}=0.06)$. The AG and GG genotypes of rs3793344 were related with borderline significant lower IGF-I levels than the AA genotype $(\mathrm{p}=0.06)$

The associations between SNPs and premenopausal breast values are presented in Table 5. There were no clear associations between the SNPs tagging the ALS gene and any of the breast measures in premenopausal women. For the SNPs tagging the IGFBP3 gene no association was found with the dense area or percentage breast density either. However, rs2132572 and rs3110697 showed statistically significant and borderline significant associations, for the dominant mode of inheritance in the non-dense area ( $\mathrm{p}=0.04$ and $\mathrm{p}=0.06$, respectively). With respect to the IGFBP1 gene, women homozygous for the minor allele (A) for rs1995051 had a smaller percentage breast density (40.3\%) than the combined group of women who were heterozygous or homozygous for the major allele $(43.5 \%)(\mathrm{p}=0.05)$. The AA genotype was also associated with a smaller dense area $(39.8 \mathrm{~cm} 2)$ compared to the other genotypes $(42.9 \mathrm{~cm} 2)$, although not statistically significantly $(\mathrm{p}=0.12)$. On the same gene, rs9658194 was found to be borderline significantly associated with percentage breast 
density ( $\mathrm{p}=0.08)$. Women who were homozygous for the major allele $(\mathrm{C})$ had a lower percentage breast density $(42.5 \%)$ compared to the other women (44.1\%). Women with a CC genotype for rs1908751, who were shown to have lower IGF-I levels in Table 4, also showed a smaller dense area and lower percent density than women with the CT or TT genotypes, although not statistically significantly ( $\mathrm{p}=0.14$ and 0.12 , respectively).

During menopause the dense area and percentage breast density decreased (Table 3). Absolute changes in breast measures over menopause by genotypes are presented in Table 6. None of the SNPs in the ALS, IGFBP3 or IGFBP1 gene was statistically significantly associated with changes in dense area or percentage breast density. One SNP in the IGFBP3 gene was associated with change of the non-dense area via the dominant mode of inheritance, rs6670 ( $\mathrm{p}=0.03)$. In the same gene, rs2453839 was borderline significantly associated with the non-dense area $(\mathrm{p}=0.06)$. Women homozygous for the major allele of rs9658194 (IGFBP1) showed a borderline significant ( $\mathrm{p}=0.08$ ) smaller decrease in dense area $(-15.3 \mathrm{~cm} 2)$ compared to the decrease in women heterozygous or homozygous for the minor allele $(-17.4 \mathrm{~cm} 2)$. However, it should be noted that the change in the small group of women who were homozygous for the minor allele $(n=20)$ was smaller than that in the heterozygotes.

Additionally, we analysed the association between all SNPs and postmenopausal measurements, however, no statistically significant associations were found with the postmenopausal dense area or percent density.

As expected modest association of borderline significance were noted with haplotypes tagged by SNPs associated with some of the outcome variables noted above. No major additional findings were noted. Complete results of the haplotype analyses are available upon request. 


\section{Discussion}

The findings in this study provide some evidence that two SNPs in the IGFBP1 gene (rs1995051 and rs1908751) are related to both circulating levels of IGF-I and mammographic density. Borderline significant relationships were observed for several SNPs in the ALS (rs17559 and rs3751893), IGFBP3 (rs2854744) and IGFBP1 (rs3793344) genes with circulating levels of IGF-I, but they were not related with mammographic density. No relations were found between genetic variants and changes in breast density over menopause.

Genetic variation in the IGFBP1 and IGFBP3 genes in relation to circulating IGF-I levels has also been studied by the Breast and Prostate Cancer Cohort Consortium (BPC3) [32]. They did not find the borderline statistically significant relationships between SNPs rs2854744 (IGFBP3) and rs1908751 (IGFBP1) and IGF-I levels that we observed. Rs1995051 and rs3793344 were not analysed in the BPC3. However, rs1995051 is in full $\mathrm{LD}\left(\mathrm{D}^{\prime}=1.0, \mathrm{r} 2=1.0\right)$ with $\mathrm{rs} 4988515$. Although statistically not significant, rs4988515 was also related to lower circulating levels of IGF-I in the BPC3 via the recessive mode of inheritance. The ALS gene was not included in the BPC3, but was studied by Canzian et al. in relation to circulating levels of IGF-I [19]. Their findings of an association between the C-allele of rs3751893 and lower IGF-I levels, are in line with our results. They found no association for rs17559, however.

Previous studies showed a relationship between a polymorphism located in the promoter region of the IGFBP3 gene (-202bp; corresponding to rs2854744 in our study) and higher circulating levels of IGFBP-3 [19, 20, 22] and IGF-I [19]. This polymorphism was also found to be related to higher percentage breast density in premenopausal women in a study conducted by Lai et al [12]. Three other studies $[11,23,33]$ as well as the current study did not find a relationship between this SNP and percentage breast density. Besides the current study, two more studies investigated various other SNPs in both the IGFBP1 and IGFBP3 genes in relation to mammographic density. As in the present study, both the study by Tamimi et al. and the study by Diorio et al. did not find any associations between the IGFBP3 genetic variants and percentage mammographic density [23, 33]. However, Tamimi et al. did find one statistically significant association (rs1065780) and one borderline significant association (rs4988515) between polymorphisms in the IGFBP1 gene and percentage breast density. Rs1065780 is in perfect pairwise linkage disequilibrium ( $\mathrm{D}^{\prime}=1.0, \mathrm{r} 2=1.0$ ) with SNP rs3793344, however, in contrast to the findings by Tamimi et al. we did not find any association with percentage breast density for rs3793344 or rs4988515. Unpublished results of the Multiethnic Cohort Study did not indicate rs3793344 to be related to breast density either (personal communication).

For rs1995051 in the IGFBP1 gene we did find a statistically significant association between this SNP and premenopausal percentage mammographic density in women via the recessive mode of inheritance $(\mathrm{p}=0.05)$. This association was a result of a smaller dense area and a larger non-dense area in women who were homozygous for the minor allele. Simultaneously, circulating levels of IGF-I were also lower in these women compared to others, although statistically not significantly. The latter 
was also observed in the BPC3 study for rs4988515 which is in full LD with rs1995051 [32]. The minor allele of Rs4988515 was found to be borderline significantly related to lower percentage density ( $\mathrm{p}=0.06$ ) by Tamimi et al. [23]. Also in the Multiethnic Cohort the minor allele of rs1995051 was associated with somewhat lower percent density, however, only in Caucasian women and statistically not significantly (personal communication). These findings suggest a possible indirect influence of genetic variation in the IGFBP1 gene on mammographic density via altered levels of IGF-I. To our knowledge no study has been conducted on the association between genetic variation in the ALS gene and mammographic density. In the present study we did not find any evidence for such a relationship.

In this study we were able to investigate changes in mammographic density over menopause. Normally, breast density decreases with age especially during menopause [34-36]. It has been thought that women in whom breast density decreases at a low rate have the highest breast cancer risk [37]. In our study no evidence was found, however, for a relation between any of the SNPs in the ALS, IGFBP3 and IGFBP1 genes and changes in dense area or percent density. The models examining change included the premenopausal breast density value in order to correct as much as possible for the phenomenon of regression to the mean[38]. When premenopausal breast density was not included, all results remained essentially the same. Only SNPs rs4316755 in ALS and rs9658194 in IGFBP1 became just significant for a change in the dense area for the dominant mode of inheritance.

With 1916 premenopausal women this study is the largest study to examine genetic variation in the IGF-pathway in relation to premenopausal mammographic density. Other strengths of the study include the use of haplotype tagging SNPs to cover common variation in three genes involved in the IGF-I pathway, and the use of both absolute and relative breast measurements. A limitation, however, may be that the women in the current study were of relatively old age. The relation between higher IGF-I levels and higher breast density was found particularly in studies including premenopausal women in which the age ranged from 42.9 - 48.3 [7-10]. Since all participants in the current study were 50 years of age or older, any associations between IGF-I related genes and breast density may be attenuated. Statistically significant results may have risen by chance, due to the large number of tests performed in this study. To evaluate this issue we used a method described by Wacholder et al. involving the calculation of a false positive report probability (FPRP) [31]. For the calculation of the FPRP a prior probability of an association is needed. Two previous studies showed several SNPs to be related to IGF-I levels $[19,33]$ increasing the prior probability to find an association. The association of rs1908751 with IGF-I levels was still statistically significant at the 0.5 FPRP-level for priors of 0.1 and higher (prior 0.1, FPRP 0.24). One other study showed associations of SNPs in the IGFBP1 gene and mammographic density [23]. Also the association of rs1995051 with mammographic density was statistically significant at the 0.5 FPRP-level for priors of 0.1 and higher (prior 0.1, FPRP 0.31).

The relation between SNPs and circulating IGF-I levels as well as changes in breast measures over menopause was investigated in a subgroup of women who went through menopause during follow-up. Due to the smaller sample size of this subgroup, the power to study the effects of the SNPs 
on circulating IGF-I levels and changes in breast measures over menopause was limited. Research in a larger study population might give more information on the possible association of common genetic variation in the ALS, IGFBP3 and IGFBP1 genes with circulating IGF-I levels and change in breast measures.

We used a state-of-the art breast density measurement method, and measurements were performed by trained observers. Some measurement error, however, is inherent to the use of routinelymade mammograms, because of differences in compression, amount of radiation etc. This particularly influences the measurements of changes in breast density. Despite this measurement error, we have been able to measure changes in breast density in relation to menopause (this study) and use of hormone therapy[39]. It cannot entirely be excluded that measurement error attenuated the relationship between genetic variation in IGF-related genes and breast density. If there is a true effect, it must have been small, however.

The associations of SNPs in the IGFBP3 gene with the non-dense area in premenopausal women (rs2132572, borderline significant) and in women who went through menopause (rs6670 significant, rs2453839 borderline significant) might be explained by the association of circulating IGFBP-3 with BMI. Some studies found a positive relation between circulating levels of IGFBP-3 and BMI [40-42], although not all [43]. In our study however, the relationship between SNPs in the IGFBP3 gene and non-dense area remained after adjustment for BMI. This might be caused by residual confounding, but the complex action and signaling of IGFBP-3 $[17,44]$ leaves other unknown possibilities which might have caused this association.

In conclusion, our data suggest that several SNPs in the ALS, IGFBP3 and IGFBP1 genes are possibly, but at the most weakly related to IGF-I levels. Several studies, including the present study, found some evidence that homozygosity for the minor allele of rs1995051 or rs4988515 (which are in high LD) is associated with lower circulating IGF-I levels and lower percent density. We did not find strong evidence to support the hypothesis that common genetic variation in different components of the IGF-I pathway are related with mammographic density.

\section{Acknowledgements}

This study was supported by Grant Number 2002/11 of the World Cancer Research Fund (WCRF). 


\section{Reference List}

1. Boyd NF, Rommens JM, Vogt K, Lee V, Hopper JL, Yaffe MJ, Paterson AD (2005) Mammographic breast density as an intermediate phenotype for breast cancer. Lancet Oncol 6:798-808

2. Guo YP, Martin LJ, Hanna W, Banerjee D, Miller N, Fishell E, Khokha R, Boyd NF (2001) Growth factors and stromal matrix proteins associated with mammographic densities. Cancer Epidemiol Biomarkers Prev 10:243-248

3. McCormack VA, dos SS, I (2006) Breast density and parenchymal patterns as markers of breast cancer risk: a meta-analysis. Cancer Epidemiol Biomarkers Prev 15:1159-1169

4. Kleinberg DL (1998) Role of IGF-I in normal mammary development. Breast Cancer Res Treat 47:201-208

5. Lee AV, Yee D (1995) Insulin-like growth factors and breast cancer. Biomed Pharmacother 49:415-421

6. Sachdev D, Yee D (2001) The IGF system and breast cancer. Endocr Relat Cancer 8:197-209

7. Boyd NF, Stone J, Martin LJ, Jong R, Fishell E, Yaffe M, Hammond G, Minkin S (2002) The association of breast mitogens with mammographic densities. Br J Cancer $87: 876-882$

8. Byrne C, Colditz GA, Willett WC, Speizer FE, Pollak M, Hankinson SE (2000) Plasma insulin-like growth factor (IGF) I, IGF-binding protein 3, and mammographic density. Cancer Res 60:3744-3748

9. Diorio C, Pollak M, Byrne C, Masse B, Hebert-Croteau N, Yaffe M, Cote G, Berube S, Morin C, Brisson J (2005) Insulin-like growth factor-I, IGF-binding protein-3, and mammographic breast density. Cancer Epidemiol Biomarkers Prev 14:1065-1073

10. Maskarinec G, Williams AE, Kaaks R (2003) A cross-sectional investigation of breast density and insulin-like growth factor I. Int J Cancer 107:991-996

11. dos Santos Silva I, Johnson N, De Stavola B, Torres-Mejia G, Fletcher O, Allen DS, Allen NE, Key TJ, Fentiman IS, Holly JM, Peto J (2006) The insulin-like growth factor system and mammographic features in premenopausal and postmenopausal women. Cancer Epidemiol Biomarkers Prev 15:449-455

12. Lai JH, Vesprini D, Zhang W, Yaffe MJ, Pollak M, Narod SA (2004) A polymorphic locus in the promoter region of the IGFBP3 gene is related to mammographic breast density. Cancer Epidemiol Biomarkers Prev 13:573-582

13. Verheus M, Peeters PH, Kaaks R, Van Noord PA, Grobbee DE, Van Gils CH (2007) Premenopausal insulin-like growth factor-I serum levels and changes in breast density over menopause. Cancer Epidemiol Biomarkers Prev 16:451-457

14. Jones JI, Clemmons DR (1995) Insulin-like growth factors and their binding proteins: biological actions. Endocr Rev 16:3-34 
15. Baxter RC (1994) Insulin-like growth factor binding proteins in the human circulation: a review. Horm Res 42:140-144

16. Rajah R, Valentinis B, Cohen P (1997) Insulin-like growth factor (IGF)-binding protein3 induces apoptosis and mediates the effects of transforming growth factor-beta1 on programmed cell death through a p53- and IGF-independent mechanism. J Biol Chem 272:12181-12188

17. Schedlich LJ, Graham LD (2002) Role of insulin-like growth factor binding protein-3 in breast cancer cell growth. Microsc Res Tech 59:12-22

18. Al Zahrani A, Sandhu MS, Luben RN, Thompson D, Baynes C, Pooley KA, Luccarini C, Munday H, Perkins B, Smith P, Pharoah PD, Wareham NJ, Easton DF, Ponder BA, Dunning AM (2006) IGF1 and IGFBP3 tagging polymorphisms are associated with circulating levels of IGF1, IGFBP3 and risk of breast cancer. Hum Mol Genet 15:1-10

19. Canzian F, McKay JD, Cleveland RJ, Dossus L, Biessy C, Rinaldi S, Landi S, Boillot C, Monnier S, Chajes V, Clavel-Chapelon F, Tehard B, Chang-Claude J, Linseisen J, Lahmann PH, Pischon T, Trichopoulos D, Trichopoulou A, Zilis D, Palli D, Tumino R, Vineis P, Berrino F, Bueno-de-Mesquita HB, Van Gils CH, Peeters PH, Pera G, Ardanaz E, Chirlaque MD, Quiros JR, Larranaga N, Martinez-Garcia C, Allen NE, Key TJ, Bingham SA, Khaw KT, Slimani N, Norat T, Riboli E, Kaaks R (2006) Polymorphisms of genes coding for insulin-like growth factor 1 and its major binding proteins, circulating levels of IGF-I and IGFBP-3 and breast cancer risk: results from the EPIC study. Br J Cancer 94:299-307

20. Deal C, Ma J, Wilkin F, Paquette J, Rozen F, Ge B, Hudson T, Stampfer M, Pollak M (2001) Novel promoter polymorphism in insulin-like growth factor-binding protein-3: correlation with serum levels and interaction with known regulators. J Clin Endocrinol Metab 86:1274-1280

21. Ren Z, Cai Q, Shu XO, Cai H, Li C, Yu H, Gao YT, Zheng W (2004) Genetic polymorphisms in the IGFBP3 gene: association with breast cancer risk and blood IGFBP-3 protein levels among Chinese women. Cancer Epidemiol Biomarkers Prev $13: 1290-1295$

22. Schernhammer ES, Hankinson SE, Hunter DJ, Blouin MJ, Pollak MN (2003) Polymorphic variation at the -202 locus in IGFBP3: Influence on serum levels of insulin-like growth factors, interaction with plasma retinol and vitamin D and breast cancer risk. Int J Cancer 107:60-64

23. Tamimi RM, Cox DG, Kraft P, Pollak MN, Haiman CA, Cheng I, Freedman ML, Hankinson SE, Hunter DJ, Colditz GA (2007) Common genetic variation in IGF1, IGFBP-1, and IGFBP-3 in relation to mammographic density: a cross-sectional study. Breast Cancer Res 9:R18

24. Riboli E, Kaaks R (1997) The EPIC Project: rationale and study design. European Prospective Investigation into Cancer and Nutrition. Int J Epidemiol 26 Suppl 1:S6-14

25. Boker LK, Van Noord PA, van der Schouw YT, Koot NV, Bueno De Mesquita HB, Riboli E, Grobbee DE, Peeters PH (2001) Prospect-EPIC Utrecht: study design and 
characteristics of the cohort population. European Prospective Investigation into Cancer and Nutrition. Eur J Epidemiol 17:1047-1053

26. (2005) A haplotype map of the human genome. Nature 437:1299-1320

27. Barrett JC, Fry B, Maller J, Daly MJ (2005) Haploview: analysis and visualization of LD and haplotype maps. Bioinformatics 21:263-265

28. Byng JW, Boyd NF, Fishell E, Jong RA, Yaffe MJ (1994) The quantitative analysis of mammographic densities. Phys Med Biol 39:1629-1638

29. Boyd NF, Martin LJ, Sun L, Guo H, Chiarelli A, Hislop G, Yaffe M, Minkin S (2006) Body size, mammographic density, and breast cancer risk. Cancer Epidemiol Biomarkers Prev 15:2086-2092

30. Renehan AG, Frystyk J, Flyvbjerg A (2006) Obesity and cancer risk: the role of the insulin-IGF axis. Trends Endocrinol Metab 17:328-336

31. Wacholder S, Chanock S, Garcia-Closas M, El Ghormli L, Rothman N (2004) Assessing the probability that a positive report is false: an approach for molecular epidemiology studies. J Natl Cancer Inst 96:434-442

32. Patel AV, Cheng I, Canzian F, Le ML, Thun MJ, Berg CD, Buring J, Calle EE, Chanock S, Clavel-Chapelon F, Cox DG, Dorronsoro M, Dossus L, Haiman CA, Hankinson SE, Henderson BE, Hoover R, Hunter DJ, Kaaks R, Kolonel LN, Kraft P, Linseisen J, Lund E, Manjer J, McCarty C, Peeters PH, Pike MC, Pollak M, Riboli E, Stram DO, Tjonneland A, Travis RC, Trichopoulos D, Tumino R, Yeager M, Ziegler RG, Feigelson HS (2008) IGF-1, IGFBP-1, and IGFBP-3 polymorphisms predict circulating IGF levels but not breast cancer risk: findings from the Breast and Prostate Cancer Cohort Consortium (BPC3). PLoS ONE 3:e2578

33. Diorio C, Brisson J, Berube S, Pollak M (2008) Genetic polymorphisms involved in insulin-like growth factor (IGF) pathway in relation to mammographic breast density and IGF levels. Cancer Epidemiol Biomarkers Prev 17:880-888

34. Boyd N, Martin L, Stone J, Little L, Minkin S, Yaffe M (2002) A longitudinal study of the effects of menopause on mammographic features. Cancer Epidemiol Biomarkers Prev 11:1048-1053

35. Maskarinec G, Pagano I, Lurie G, Kolonel LN (2006) A longitudinal investigation of mammographic density: the multiethnic cohort. Cancer Epidemiol Biomarkers Prev $15: 732-739$

36. Vachon CM, Pankratz VS, Scott CG, Maloney SD, Ghosh K, Brandt KR, Milanese T, Carston MJ, Sellers TA (2007) Longitudinal trends in mammographic percent density and breast cancer risk. Cancer Epidemiol Biomarkers Prev 16:921-928

37. Kerlikowske K, Ichikawa L, Miglioretti DL, Buist DS, Vacek PM, Smith-Bindman R, Yankaskas B, Carney PA, Ballard-Barbash R (2007) Longitudinal measurement of clinical mammographic breast density to improve estimation of breast cancer risk. J Natl Cancer Inst 99:386-395 
38. Twisk JWR (2005) Applied Longitudinal data analysis for epidemiology. A practical guide. Cambridge University Press, Cambridge

39. van Duijnhoven FJ, Peeters PH, Warren RM, Bingham SA, Van Noord PA, Monninkhof EM, Grobbee DE, Van Gils CH (2007) Postmenopausal hormone therapy and changes in mammographic density. J Clin Oncol 25:1323-1328

40. Allen NE, Appleby PN, Kaaks R, Rinaldi S, Davey GK, Key TJ (2003) Lifestyle determinants of serum insulin-like growth-factor-I (IGF-I), C-peptide and hormone binding protein levels in British women. Cancer Causes Control 14:65-74

41. Holmes MD, Pollak MN, Hankinson SE (2002) Lifestyle correlates of plasma insulinlike growth factor I and insulin-like growth factor binding protein 3 concentrations. Cancer Epidemiol Biomarkers Prev 11:862-867

42. Voskuil DW, Bueno De Mesquita HB, Kaaks R, Van Noord PA, Rinaldi S, Riboli E, Grobbee DE, Peeters PH (2001) Determinants of circulating insulin-like growth factor (IGF)-I and IGF binding proteins 1-3 in premenopausal women: physical activity and anthropometry (Netherlands). Cancer Causes Control 12:951-958

43. Lukanova A, Lundin E, Zeleniuch-Jacquotte A, Muti P, Mure A, Rinaldi S, Dossus L, Micheli A, Arslan A, Lenner P, Shore RE, Krogh V, Koenig KL, Riboli E, Berrino F, Hallmans G, Stattin P, Toniolo P, Kaaks R (2004) Body mass index, circulating levels of sex-steroid hormones, IGF-I and IGF-binding protein-3: a cross-sectional study in healthy women. Eur J Endocrinol 150:161-171

44. Baxter RC (2001) Signalling pathways involved in antiproliferative effects of IGFBP-3: a review. Mol Pathol 54:145-148 
Table 1: Haplotype tagging SNPs

\begin{tabular}{lcccl}
\hline SNP & Haplotype block & Polymorphism & $\begin{array}{c}\text { Minor allele } \\
\text { frequency (\%) }\end{array}$ & Position \\
\hline ALS & 1 & $\mathrm{C} \rightarrow \mathrm{T}$ & 10.5 & Exon 2 \\
rs17559 & 1 & $\mathrm{~A} \rightarrow \mathrm{C}$ & 25.4 & Promotor region \\
rs4316755 & 1 & $\mathrm{~T} \rightarrow \mathrm{C}$ & 16.9 & Exon 2 \\
rs3751893 & & & \\
& & & & \\
IGFBP3 & 1 & $\mathrm{~A} \rightarrow \mathrm{T}$ & 21.6 & Exon 4; 3' UTR \\
rs6670 & 2 & $\mathrm{~T} \rightarrow \mathrm{C}$ & 17.4 & Exon 4; 3' UTR \\
rs2453839 & 3 & $\mathrm{G} \rightarrow \mathrm{A}$ & 45.8 & Intron 3 \\
rs3110697 & 3 & $\mathrm{G} \rightarrow \mathrm{T}$ & 44.4 & Promoter region \\
rs2854744 & 3 & $\mathrm{G} \rightarrow \mathrm{A}$ & 25.2 & Promoter region \\
rs2132572 & & & & \\
IGFBP1 & & $\mathrm{G} \rightarrow \mathrm{A}$ & 27.5 & Promoter region \\
rs1995051 & 1 & $\mathrm{C} \rightarrow \mathrm{T}$ & 33.2 & Promoter region \\
rs3763497 & 2 & $\mathrm{~A} \rightarrow \mathrm{G}$ & 40.8 & Intron 1 \\
rs3793344 & 2 & $\mathrm{C} \rightarrow \mathrm{A}$ & 20.2 & Intron 1 \\
rs9658194 & 2 & $\mathrm{G} \rightarrow \mathrm{A}$ & 6.0 & Exon 4 \\
rs4988515 & 2 & $\mathrm{C} \rightarrow \mathrm{T}$ & 25.5 & Downstream \\
rs1908751 & 2 & & & \\
\hline
\end{tabular}

$\mathrm{SNP}=$ Single Nucleotide Polymorphism

Table 2: Baseline characteristics of the study population

\begin{tabular}{lcc}
\hline & $\begin{array}{c}\text { All premenopausal women } \\
(\mathrm{n}=1916)\end{array}$ & $\begin{array}{c}\text { Women who became postmenopausal } \\
\text { during follow-up }(\mathrm{n}=657)\end{array}$ \\
\hline Age at baseline (years (SD)) & $51.0(2.0)$ & $51.4(2.1)$ \\
Age at follow-up (years (SD)) & n.a. & $55.8(2.3)$ \\
BMI at baseline (kg/m2 (SD)) & $25.4(4.0)$ & $25.1(3.8)$ \\
BMI at follow-up (kg/m2 (SD)) & n.a. & $25.7(4.4)$ \\
& $13.3(1.5)$ & $13.2(1.4)$ \\
Age at menarche (years (SD)) & $24.9(4.1)$ & $25.1(3.9)$ \\
Age at first birth (years (SD)) & n.a. & $52.0(2.8)$ \\
Age at menopause (years (SD)) & & \\
Parity & $241(12.6)$ & $74(11.2)$ \\
$\quad$ Nulliparous (nr. (\%)) & $172(9.0)$ & $54(8.2)$ \\
1 & $936(48.9)$ & $322(49.0)$ \\
2 & $426(22.2)$ & $160(24.4)$ \\
3+ & $10(0.5)$ & $3(0.5)$ \\
Hysterectomy (nr. (\%)) & $55(2.9)$ & $19(2.9)$ \\
Ovariectomy (one) (nr. (\%)) & n.a. & $5.4(1.1)$ \\
Time between mammogram & & \\
measurements (years (SD)) & n.a. & $114.7(29.0)$ \\
Serum levels of IGF-1 (ng/mL) & & \\
\hline
\end{tabular}

* This is a subgroup of all premenopausal women, who have both a pre- and a postmenopausal mammogram as well as measured premenopausal IGF-I serum levels.

$\mathrm{SD}=$ standard deviation $; \mathrm{BMI}=$ Body Mass Index $;$ n.a. $=$ not applicable 
Table 3: Median pre- and postmenopausal breast values and changes in breast values over menopause

\begin{tabular}{|c|c|c|c|c|}
\hline & \multirow{2}{*}{$\begin{array}{l}\text { All premenopausal } \\
\text { women }(n=1916) \\
\text { Pre menopause } \\
\text { (interquartile range) }\end{array}$} & \multicolumn{3}{|c|}{$\begin{array}{l}\text { Women who became postmenopausal during } 5.5 \text { years of follow up } \\
(n=657)^{a}\end{array}$} \\
\hline & & $\begin{array}{l}\text { Pre menopause } \\
\text { (interquartile range) }\end{array}$ & $\begin{array}{l}\text { Post menopause } \\
\text { (interquartile range) }\end{array}$ & $\begin{array}{c}\text { Absolute change over } \\
\text { menopause } \\
\text { (interquartile range) }\end{array}$ \\
\hline Dense area (in cm²) & $44.3(29.8 ; 59.3)$ & $42.8(30.1 ; 57.4)$ & $26.9(14.5 ; 37.8)$ & $-11.9(-23.6 ;-3.9)$ \\
\hline Non-dense area (in $\mathrm{cm}^{2}$ ) & 58.7 (36.9; 92.8) & 56.7 (36.1; 89.2) & $63.3(34.3 ; 94.1)$ & $0.5(-13.6 ; 14.8)$ \\
\hline Percent breast density & $45.1(27.2 ; 59.7)$ & $44.6(27.4 ; 59.4)$ & $34.3(16.5 ; 52.1)$ & $-6.7(-15.2 ; 0.7)$ \\
\hline
\end{tabular}

${ }^{a}$ This is a subgroup of all premenopausal women, who have both a pre- and a postmenopausal mammogram as well as measured premenopausal IGF-I serum levels 
Table 4: Association between SNPs and mean IGF-I levels $(\mathrm{ng} / \mathrm{mL})$ in women who became postmenopausal during follow-up $(n=657)^{\mathrm{a}}$

\begin{tabular}{|c|c|c|c|c|c|c|c|c|}
\hline Block & SNP & $\mathrm{N}$ & Genotype & Mean level $^{\mathrm{b}}$ & $95 \% \mathrm{Cl}$ & $p$-value ${ }^{c}$ & $p$-value ${ }^{d}$ & $p$-value ${ }^{e}$ \\
\hline & $A L S$ & & & & & & & \\
\hline \multirow[t]{2}{*}{1} & rs17559 & 523 & $\mathrm{CC}$ & 113.9 & $111.4-116.4$ & 0.08 & & \\
\hline & & 122 & $\mathrm{CT} / \mathrm{TT}$ & 109.0 & $104.1-114.0$ & & & \\
\hline \multirow[t]{3}{*}{1} & rs4316755 & 357 & $A A$ & 114.2 & $111.3-117.2$ & 0.21 & 0.25 & 0.18 \\
\hline & & 238 & $A C$ & 111.9 & $108.4-115.6$ & & & \\
\hline & & 42 & $\mathrm{CC}$ & 108.1 & 99.8 - 116.6 & & & \\
\hline \multirow[t]{3}{*}{1} & rs3751893 & 444 & TT & 114.3 & $111.7-117.0$ & 0.07 & & \\
\hline & & 197 & $\mathrm{CT} / \mathrm{CC}$ & 109.9 & $106.0-113.9$ & & & \\
\hline & IGFBP3 & & & & & & & \\
\hline \multirow[t]{3}{*}{1} & rs6670 & 398 & AA & 111.8 & $109.0-114.6$ & 0.11 & 0.54 & 0.75 \\
\hline & & 215 & AT & 116.3 & $112.4-120.3$ & & & \\
\hline & & 31 & TT & 110.1 & $100.5-120.3$ & & & \\
\hline \multirow[t]{3}{*}{2} & rs2453839 & 431 & TT & 112.0 & $109.3-114.7$ & 0.24 & 0.61 & 0.73 \\
\hline & & 206 & CT & 115.2 & $111.3-119.2$ & & & \\
\hline & & 20 & $\mathrm{CC}$ & 109.8 & $97.9-122.4$ & & & \\
\hline \multirow[t]{3}{*}{3} & rs3110697 & 183 & GG & 110.9 & $106.9-115.1$ & 0.25 & 0.64 & 0.76 \\
\hline & & 326 & $A G$ & 114.5 & $111.4-117.7$ & & & \\
\hline & & 130 & AA & 111.9 & $107.1-116.8$ & & & \\
\hline \multirow[t]{3}{*}{3} & rs2854744 & 198 & GG & 112.5 & $108.6-116.5$ & 0.82 & 0.08 & 0.23 \\
\hline & & 328 & GT & 114.6 & $111.4-117.7$ & & & \\
\hline & & 106 & TT & 108.4 & $103.1-113.8$ & & & \\
\hline \multirow[t]{4}{*}{3} & rs2132572 & 349 & GG & 111.7 & $108.7-114.6$ & 0.29 & 0.93 & 0.75 \\
\hline & & 246 & GA & 114.2 & $110.7-117.8$ & & & \\
\hline & & 47 & AA & 113.1 & $105.1-121.4$ & & & \\
\hline & IGFBP1 & & & & & & & \\
\hline \multirow[t]{3}{*}{1} & rs1995051 & 327 & GG & 112.9 & $109.8-116.0$ & 0.99 & 0.06 & 0.10 \\
\hline & & 266 & GA & 114.2 & $110.8-117.7$ & & & \\
\hline & & 49 & AA & 105.7 & $98.2-113.6$ & & & \\
\hline \multirow[t]{3}{*}{2} & rs3763497 & 284 & $\mathrm{CC}$ & 113.6 & $110.4-117.0$ & 0.68 & 0.82 & 0.75 \\
\hline & & 282 & CT & 112.8 & $109.5-116.1$ & & & \\
\hline & & 68 & TT & 112.4 & $105.8-119.2$ & & & \\
\hline \multirow[t]{3}{*}{2} & rs3793344 & 234 & AA & 116.0 & $112.3-119.7$ & 0.06 & 0.38 & 0.13 \\
\hline & & 295 & $A G$ & 111.8 & $108.6-115.1$ & & & \\
\hline & & 114 & GG & 111.1 & $105.9-116.3$ & & & \\
\hline \multirow[t]{3}{*}{2} & rs9658194 & 422 & $\mathrm{CC}$ & 113.8 & $111.1-116.5$ & 0.29 & 0.88 & 0.79 \\
\hline & & 200 & CA & 111.2 & $107.4-115.2$ & & & \\
\hline & & 20 & AA & 112.0 & $100.0-124.7$ & & & \\
\hline \multirow[t]{2}{*}{2} & rs4988515 & 546 & GG & 112.8 & $110.4-115.2$ & 0.50 & & \\
\hline & & 63 & GA/AA & 110.3 & $103.5-117.3$ & & & \\
\hline \multirow[t]{3}{*}{2} & rs1908751 & 346 & $\mathrm{CC}$ & 110.9 & $108.0-113.9$ & 0.04 & 0.15 & 0.41 \\
\hline & & 249 & CT & 117.2 & $113.7-120.8$ & & & \\
\hline & & 45 & TT & 107.3 & $99.4-115.5$ & & & \\
\hline
\end{tabular}

${ }^{a}$ This is a subgroup of all premenopausal women, who have both a pre- and a postmenopausal mammogram as well as measured premenopausal IGF-I serum levels.

${ }^{\mathrm{b}}$ Mean levels were square root transformed and presented here in the original scale.

${ }^{c} \mathrm{P}$-value for dominant mode of inheritance.

${ }^{\mathrm{d}} \mathrm{P}$-value for recessive mode of inheritance.

${ }^{\mathrm{e}} \mathrm{P}$-value for additive mode of inheritance.

$\mathrm{SNP}=$ single nucleotide polymorphis $\mathrm{m} ; \mathrm{CI}=$ confidence interval 
Table 5: Associations between SNPs and mean premenopausal breast measures in the total group of premenopausal women ( $\mathrm{n}=1916)$

\begin{tabular}{|c|c|c|c|c|c|c|c|c|c|c|c|c|c|c|c|c|c|c|}
\hline \multirow[b]{2}{*}{$A L S$} & \multicolumn{8}{|c|}{ Dense area $^{a}$} & \multicolumn{5}{|c|}{ Non-dense area ${ }^{a}$} & \multicolumn{5}{|c|}{$\%$ breast density } \\
\hline & & & & & & & & & & & & & & & & & & \\
\hline Block & SNP & $\mathrm{N}$ & Genotype & Mean & $95 \% \mathrm{Cl}$ & $p$-value ${ }^{b}$ & $p$-value ${ }^{c}$ & $p$-value ${ }^{d}$ & Mean & $95 \% \mathrm{Cl}$ & $p$-value ${ }^{b}$ & $p$-value ${ }^{c}$ & $p$-value ${ }^{d}$ & Mean & $95 \% \mathrm{Cl}$ & $p$-value ${ }^{b}$ & $p$-value ${ }^{c}$ & $p$-value ${ }^{d}$ \\
\hline \multirow[t]{2}{*}{1} & rs17559 & 1505 & CC & 42.6 & $41.5-43.8$ & 0.49 & & & 63.5 & $62.0-65.1$ & 0.38 & & & 43.1 & $42.2-44.0$ & 0.77 & & \\
\hline & & 379 & $\mathrm{CT} / \mathrm{TT}$ & 41.7 & $39.5-44.0$ & & & & 61.9 & $58.9-65.1$ & & & & 43.4 & $41.6-45.2$ & & & \\
\hline \multirow[t]{3}{*}{1} & rs4316755 & 1031 & AA & 42.8 & $41.4-44.2$ & 0.68 & 0.48 & 0.46 & 63.1 & $61.2-65.0$ & 0.89 & 0.25 & 0.27 & 43.4 & $42.2-44.5$ & 0.83 & 0.96 & 0.99 \\
\hline & & 740 & $A C$ & 42.6 & $40.9-44.2$ & & & & 63.4 & $61.2-65.7$ & & & & 43.2 & $41.8-44.5$ & & & \\
\hline & & 108 & $\mathrm{CC}$ & 41.1 & $36.7-45.5$ & & & & 59.7 & $54.1-65.6$ & & & & 43.4 & $39.9-46.8$ & & & \\
\hline \multirow[t]{3}{*}{1} & rs3751893 & 1286 & TT & 42.7 & $41.4-43.9$ & 0.62 & 0.85 & 0.89 & 62.4 & $60.7-64.1$ & 0.27 & 0.89 & 0.80 & 43.5 & $42.5-44.5$ & 0.42 & 0.94 & 0.99 \\
\hline & & 538 & CT & 42.0 & $40.2-44.0$ & & & & 64.2 & $61.5-66.9$ & & & & 42.7 & $41.1-44.2$ & & & \\
\hline & & 48 & $\mathrm{CC}$ & 43.1 & $36.9-49.9$ & & & & 63.6 & $55.0-72.7$ & & & & 43.5 & $38.3-48.6$ & & & \\
\hline \multicolumn{19}{|c|}{ IGFBP3 } \\
\hline Block & SNP & $\mathrm{N}$ & Genotype & Mean & $95 \% \mathrm{Cl}$ & $p$-value ${ }^{b}$ & $p$-value ${ }^{c}$ & $p$-value ${ }^{d}$ & Mean & $95 \% \mathrm{Cl}$ & $p$-value ${ }^{b}$ & $p$-value ${ }^{c}$ & $p$-value ${ }^{d}$ & Mean & $95 \% \mathrm{Cl}$ & $p$-value ${ }^{b}$ & $p$-value ${ }^{c}$ & $p$-value ${ }^{d}$ \\
\hline \multirow[t]{3}{*}{1} & rs 6670 & 1148 & AA & 42.9 & $41.6-44.2$ & 0.36 & 0.66 & 0.57 & 62.6 & $60.8-64.4$ & 0.45 & 0.19 & 0.18 & 43.6 & $42.6-44.7$ & 0.27 & 0.40 & 0.33 \\
\hline & & 634 & AT & 42.0 & $40.2-43.8$ & & & & 63.2 & $60.8-65.7$ & & & & 42.8 & $41.4-44.2$ & & & \\
\hline & & 87 & TT & 41.5 & $36.9-46.4$ & & & & 67.4 & $60.7-74.3$ & & & & 41.6 & $37.8-45.5$ & & & \\
\hline \multirow[t]{3}{*}{2} & rs2453839 & 1297 & TT & 42.2 & $40.9-43.4$ & 0.37 & 0.34 & 0.31 & 62.8 & $61.1-64.5$ & 0.52 & 0.29 & 0.34 & 43.2 & $42.2-44.2$ & 0.99 & 0.31 & 0.32 \\
\hline & & 567 & TC & 42.9 & $41.1-44.8$ & & & & 64.2 & $61.6-66.8$ & & & & 43.0 & $41.5-44.5$ & & & \\
\hline & & 50 & $\mathrm{cc}$ & 45.5 & $39.3-52.3$ & & & & 58.6 & $50.5-67.2$ & & & & 45.8 & $40.7-50.8$ & & & \\
\hline \multirow[t]{3}{*}{3} & rs3110697 & 549 & $G G$ & 43.3 & $41.4-45.2$ & 0.37 & 0.47 & 0.33 & 60.7 & $58.2-63.3$ & 0.06 & 0.53 & 0.15 & 44.2 & $42.7-45.7$ & 0.19 & 0.49 & 0.24 \\
\hline & & 905 & $A G$ & 42.4 & $40.9-43.9$ & & & & 63.7 & $61.7-65.8$ & & & & 43.1 & $41.9-44.3$ & & & \\
\hline & & 394 & AA & 41.8 & $39.6-44.1$ & & & & 63.7 & $60.6-66.9$ & & & & 42.8 & $41.0-44.6$ & & & \\
\hline \multirow[t]{3}{*}{3} & rs2854744 & 553 & $G G$ & 42.4 & $40.6-44.2$ & 0.95 & 0.36 & 0.54 & 64.0 & $61.4-66.7$ & 0.40 & 0.12 & 0.13 & 42.9 & $41.3-44.4$ & 0.69 & 0.22 & 0.28 \\
\hline & & 944 & GT & 41.9 & $40.5-43.4$ & & & & 63.4 & $61.4-65.4$ & & & & 42.9 & $41.7-44.0$ & & & \\
\hline & & 346 & TT & 43.4 & $41.0-45.8$ & & & & 60.8 & $57.6-64.0$ & & & & 44.2 & $42.3-46.1$ & & & \\
\hline \multirow[t]{3}{*}{3} & rs2132572 & 1045 & $G G$ & 42.7 & $41.4-44.1$ & 0.40 & 0.80 & 0.96 & 61.8 & $59.9-63.7$ & 0.04 & 0.46 & 0.26 & 43.6 & $42.5-44.7$ & 0.26 & 0.49 & 0.38 \\
\hline & & 691 & GA & 41.7 & $40.0-43.3$ & & & & 64.7 & $62.3-67.1$ & & & & 42.7 & $41.4-44.1$ & & & \\
\hline & & 124 & AA & 42.8 & $38.9-46.9$ & & & & 65.1 & $59.6-70.8$ & & & & 42.0 & $38.8-45.3$ & & & \\
\hline
\end{tabular}


Table 5 (continued): Associations between SNPs and mean premenopausal breast measures in the total group of premenopausal women ( $\mathrm{n}=1916$ )

\begin{tabular}{|c|c|c|c|c|c|c|c|c|c|c|c|c|c|c|c|c|c|c|}
\hline \multirow[b]{2}{*}{ IGFBP1 } & \multicolumn{8}{|c|}{ Dense area $^{a}$} & \multicolumn{5}{|c|}{ Non-dense area $^{a}$} & \multicolumn{5}{|c|}{$\%$ breast density } \\
\hline & & & & & & & & & & & & & & & & & & \\
\hline Block & SNP & $\mathrm{N}$ & Genotype & Mean & $95 \% \mathrm{Cl}$ & $p$-value ${ }^{b}$ & $p$-value ${ }^{c}$ & $p$-value ${ }^{d}$ & Mean & $95 \% \mathrm{Cl}$ & $p$-value ${ }^{b}$ & $p$-value ${ }^{c}$ & $p$-value ${ }^{d}$ & Mean & $95 \% \mathrm{Cl}$ & $p$-value ${ }^{b}$ & $p$-value ${ }^{c}$ & $p$-value ${ }^{d}$ \\
\hline \multirow[t]{3}{*}{1} & rs1995051 & 977 & $G G$ & 42.7 & $41.2-44.1$ & 0.94 & 0.12 & 0.16 & 63.2 & $61.2-65.2$ & 0.98 & 0.15 & 0.19 & 43.3 & $42.2-44.5$ & 0.81 & 0.05 & 0.07 \\
\hline & & 758 & GA & 43.1 & $41.5-44.7$ & & & & 62.5 & $60.3-64.8$ & & & & 43.7 & $42.4-45.0$ & & & \\
\hline & & 135 & $A A$ & 39.8 & $36.2-43.6$ & & & & 65.9 & $61.7-72.6$ & & & & 40.3 & $37.2-43.3$ & & & \\
\hline \multirow[t]{3}{*}{2} & rs3763497 & 825 & $\mathrm{CC}$ & 42.6 & $41.1-44.2$ & 0.85 & 0.27 & 0.39 & 64.1 & $61.9-66.3$ & 0.28 & 0.71 & 0.50 & 42.7 & $41.5-44.0$ & 0.31 & 0.33 & 0.25 \\
\hline & & 830 & CT & 42.0 & $40.5-43.5$ & & & & 62.5 & $60.4-64.7$ & & & & 43.4 & $42.1-44.6$ & & & \\
\hline & & 201 & TT & 44.2 & $41.0-47.5$ & & & & 62.4 & $58.2-66.8$ & & & & 44.4 & $41.8-46.9$ & & & \\
\hline \multirow[t]{3}{*}{2} & rs3793344 & 659 & AA & 42.6 & $40.9-44.4$ & 0.84 & 0.21 & 0.40 & 63.2 & $60.8-65.6$ & 0.89 & 0.94 & 0.91 & 43.1 & $41.7-44.5$ & 0.82 & 0.33 & 0.40 \\
\hline & & 901 & $A G$ & 41.9 & $40.4-43.4$ & & & & 63.0 & $61.0-65.0$ & & & & 43.0 & $41.8-44.2$ & & & \\
\hline & & 315 & GG & 44.0 & $41.5-46.6$ & & & & 62.9 & $59.5-66.4$ & & & & 44.2 & $42.1-46.2$ & & & \\
\hline \multirow[t]{3}{*}{2} & rs9658194 & 1190 & $\mathrm{cc}$ & 41.9 & $40.6-43.2$ & 0.14 & 0.33 & 0.26 & 64.2 & $62.4-66.0$ & 0.13 & 0.15 & 0.11 & 42.5 & $41.5-43.6$ & 0.08 & 0.15 & 0.10 \\
\hline & & 613 & $\mathrm{CA}$ & 43.3 & $41.5-45.1$ & & & & 62.4 & $59.9-64.9$ & & & & 43.8 & $42.4-45.3$ & & & \\
\hline & & 72 & AA & 45.0 & $39.8-50.6$ & & & & 58.2 & $51.4-65.5$ & & & & 46.1 & $41.9-50.4$ & & & \\
\hline \multirow[t]{2}{*}{2} & rs4988515 & 1567 & GG & 42.6 & $41.5-43.8$ & 0.98 & & & 62.9 & $61.4-64.5$ & 0.21 & & & 43.3 & $42.4-44.3$ & 0.29 & & \\
\hline & & 208 & $\mathrm{GA} / \mathrm{AA}$ & 42.6 & $39.5-45.7$ & & & & 65.8 & $61.6-70.2$ & & & & 41.9 & $39.4-44.4$ & & & \\
\hline \multirow[t]{3}{*}{2} & rs1908751 & 1029 & $\mathrm{Cc}$ & 41.7 & $40.3-43.1$ & 0.14 & 0.50 & 0.35 & 63.9 & $62.0-65.8$ & 0.34 & 0.33 & 0.27 & 42.5 & $41.4-43.6$ & 0.12 & 0.27 & 0.18 \\
\hline & & 691 & CT & 43.2 & $41.5-44.9$ & & & & 62.8 & $60.5-65.2$ & & & & 43.6 & $42.3-45.0$ & & & \\
\hline & & 124 & TT & 43.7 & $39.8-47.9$ & & & & 60.7 & $55.4-66.2$ & & & & 44.8 & $41.6-48.0$ & & & \\
\hline
\end{tabular}

Mean values and CIs of the non-dense area and percentage breast density were adjusted for BMI.

${ }^{\text {a }}$ Mean levels were square root transformed and presented here in the original scale.

${ }^{\text {b }}$ P-value for dominant mode of inheritance.

P-value for recessive mode of inheritance.

${ }^{\mathrm{Q}} \mathrm{P}$-value for additive mode of inheritance.

$\mathrm{SNP}=$ single nucleotide polymorphis $\mathrm{m} ; \mathrm{CI}=$ confidence interval 
Table 6: Associations between SNPs and changes in breast measures during menopause, in women who became postmenopausal during follow-up ( $\mathrm{n}=657$ )

\begin{tabular}{|c|c|c|c|c|c|c|c|c|c|c|c|c|c|c|c|c|c|c|}
\hline \multirow{2}{*}{$A L S$} & \multicolumn{8}{|c|}{ Dense area } & \multicolumn{5}{|c|}{ Non-dense area } & \multicolumn{5}{|c|}{$\%$ breast density } \\
\hline & & & & & & & & & & & & & & & & & & \\
\hline Block & SNP & $N$ & Genotype & Mean & $95 \% \mathrm{Cl}$ & $p$-value ${ }^{a}$ & $p$-value ${ }^{b}$ & $p$-value ${ }^{c}$ & Mean & $95 \% \mathrm{Cl}$ & $p$-value ${ }^{a}$ & $p$-value ${ }^{b}$ & $p$-value ${ }^{c}$ & Mean & $95 \% \mathrm{Cl}$ & $p$-value ${ }^{a}$ & $p$-value ${ }^{b}$ & $p$-value ${ }^{c}$ \\
\hline \multirow[t]{2}{*}{1} & Rs17559 & 523 & $\mathrm{CC}$ & -16.4 & $-17.7 ;-15.1$ & 0.27 & & & -0.1 & $-2.3 ; 2.1$ & 0.18 & & & -7.4 & $-8.5 ;-6.3$ & 0.60 & & \\
\hline & & 122 & $\mathrm{CT} / \mathrm{TT}$ & -14.8 & $-17.5 ;-12.1$ & & & & 3.4 & $-1.2 ; 8.0$ & & & & -8.1 & $-10.4 ;-5.7$ & & & \\
\hline \multirow[t]{3}{*}{1} & rs4316755 & 357 & $\mathrm{AA}$ & -15.4 & $-17.0 ;-13.9$ & 0.11 & 0.46 & 0.31 & -0.1 & $-2.8 ; 2.6$ & 0.60 & 0.53 & 0.49 & -6.8 & $-8.2 ;-5.5$ & 0.17 & 0.18 & 0.13 \\
\hline & & 238 & $A C$ & -17.2 & $-19.2 ;-15.3$ & & & & 0.6 & $-2.7 ; 4.0$ & & & & -8.0 & $-9.6 ;-6.3$ & & & \\
\hline & & 42 & $\mathrm{CC}$ & -18.0 & $-22.5 ;-13.4$ & & & & 2.8 & $-5.0 ; 10.5$ & & & & -10.0 & $-13.9 ;-6.1$ & & & \\
\hline \multirow[t]{2}{*}{1} & rs3751893 & 444 & TT & -15.8 & $-17.2 ;-14.4$ & 0.49 & & & 0.1 & $-2.3 ; 2.5$ & 0.95 & & & -7.3 & $-8.5 ;-6.1$ & 0.81 & & \\
\hline & & 197 & $\mathrm{CT} / \mathrm{CC}$ & -16.7 & $-18.8 ;-14.5$ & & & & 0.3 & $-3.3 ; 3.9$ & & & & -7.6 & $-9.4 ;-5.8$ & & & \\
\hline \multicolumn{19}{|c|}{ IGFBP3 } \\
\hline Block & SNP & $N$ & Genotype & Mean & $95 \% \mathrm{Cl}$ & $p$-value ${ }^{a}$ & $p$-value ${ }^{b}$ & $p$-value ${ }^{c}$ & Mean & $95 \% \mathrm{Cl}$ & $p$-value ${ }^{a}$ & $p$-value ${ }^{b}$ & $p$-value ${ }^{c}$ & Mean & $95 \% \mathrm{Cl}$ & $p$-value ${ }^{a}$ & $p$-value ${ }^{b}$ & $p$-value ${ }^{c}$ \\
\hline \multirow[t]{3}{*}{1} & rs6670 & 398 & $\mathrm{AA}$ & -16.3 & $-17.8 ;-14.8$ & 0.87 & 0.32 & 0.36 & -1.3 & $-3.9 ; 1.2$ & 0.03 & 0.55 & 0.35 & -7.2 & $-8.5 ;-5.9$ & 0.38 & 0.24 & 0.21 \\
\hline & & 215 & AT & -15.7 & $-17.7 ;-13.7$ & & & & 3.1 & $-0.3 ; 6.6$ & & & & -7.8 & $-9.6 ;-6.1$ & & & \\
\hline & & 31 & TT & -18.8 & $-24.1 ;-13.5$ & & & & 3.2 & $-5.9 ; 12.2$ & & & & -10.2 & $-14.8 ; 5.7$ & & & \\
\hline \multirow[t]{3}{*}{2} & rs2453839 & 431 & TT & -15.6 & $-17.0 ;-14.2$ & 0.37 & 0.45 & 0.53 & 0.1 & $-2.4 ; 2.5$ & 0.70 & 0.06 & 0.06 & -7.2 & $-8.4 ;-6.0$ & 0.50 & 0.16 & 0.15 \\
\hline & & 206 & TC & -17.0 & $-19.1 ;-15.0$ & & & & -0.1 & $-3.6 ; 3.4$ & & & & -7.6 & $-9.3 ;-5.8$ & & & \\
\hline & & 20 & $\mathrm{CC}$ & -13.5 & $-20.1 ;-6.9$ & & & & 10.9 & $-0,3 ; 22.1$ & & & & -11.4 & $-17.1 ;-5.8$ & & & \\
\hline \multirow[t]{3}{*}{3} & rs3110697 & 183 & $\mathrm{GG}$ & -15.7 & $-17.9 ;-13.5$ & 0.82 & 0.77 & 0.75 & 0.4 & $-3.4 ; 3.1$ & 0.95 & 0.57 & 0.67 & -7.1 & $-9.0 ;-5.2$ & 0.68 & 0.94 & 0.79 \\
\hline & & 326 & $A G$ & -15.9 & $-17.6 ;-14.3$ & & & & 0.7 & $-2.1 ; 3.5$ & & & & -7.6 & $-9.0 ;-6.1$ & & & \\
\hline & & 130 & $\mathrm{AA}$ & -16.3 & $-18.9 ;-13.7$ & & & & -0.9 & $-5.3 ; 3.6$ & & & & -7.5 & $-9.7 ;-5.2$ & & & \\
\hline \multirow[t]{3}{*}{3} & rs2854744 & 198 & $\mathrm{GG}$ & -15.5 & $-17.6 ;-13.4$ & 0.58 & 0.32 & 0.64 & -1.6 & $-5.2 ; 2.0$ & 0.22 & 0.36 & 0.21 & -6.6 & $-8.4 ;-4.8$ & 0.29 & 0.49 & 0.99 \\
\hline & & 328 & GT & -16.7 & $-18.3 ;-15.1$ & & & & 0.7 & $2.1 ; 3.5$ & & & & -8.1 & $-9.6 ;-6.8$ & & & \\
\hline & & 106 & TT & -14.6 & $-17.5 ;-11.8$ & & & & 2.3 & $-2.6 ; 7.3$ & & & & -6.6 & $-9.1 ;-4.2$ & & & \\
\hline \multirow[t]{3}{*}{3} & rs2132572 & 349 & $\mathrm{GG}$ & -16.2 & $-17.7 ;-14.6$ & 0.83 & 0.25 & 0.28 & 0.6 & $-2.1 ; 3.3$ & 0.93 & 0.10 & 0.14 & -7.3 & $-8.7 ;-6.0$ & 0.74 & 0.16 & 0.23 \\
\hline & & 246 & $\mathrm{GA}$ & -16.3 & $-18.2 ;-14.5$ & & & & 1.5 & $-1.7 ; 4.8$ & & & & -8.2 & $-9.8 ;-6.6$ & & & \\
\hline & & 47 & AA & -13.6 & $-18.0 ;-9.4$ & & & & -5.4 & $-12.8 ; 2.0$ & & & & -4.9 & $-8.6 ;-1.2$ & & & \\
\hline
\end{tabular}


Table 6 (continued): Associations between SNPs and changes in breast measures during menopause, in women who became postmenopausal during follow-up $(\mathrm{n}=657)$

\begin{tabular}{|c|c|c|c|c|c|c|c|c|c|c|c|c|c|c|c|c|c|c|}
\hline \multirow{2}{*}{ IGFBP1 } & \multicolumn{8}{|c|}{ Dense area } & \multicolumn{5}{|c|}{ Non-dense area $^{a}$} & \multicolumn{5}{|c|}{$\%$ breast density } \\
\hline & & & & & & & & & & & & & & & & & & \\
\hline Block & SNP & $\mathrm{N}$ & Genotype & Mean & $95 \% \mathrm{Cl}$ & $p$-value ${ }^{a}$ & $p$-value ${ }^{b}$ & $p$-value ${ }^{c}$ & Mean & $95 \% \mathrm{Cl}$ & $p$-value ${ }^{a}$ & $p$-value ${ }^{b}$ & $p$-value ${ }^{c}$ & Mean & $95 \% \mathrm{Cl}$ & $p$-value ${ }^{a}$ & $p$-value ${ }^{b}$ & $p$-value ${ }^{c}$ \\
\hline \multirow[t]{3}{*}{1} & rs1995051 & 327 & GG & -16.4 & $-18.0 ;-14.7$ & 0.55 & 0.27 & 0.26 & 0.1 & $-2.7 ; 3.0$ & 0.91 & 0.38 & 0.41 & -7.5 & $-8.9 ;-6.1$ & 0.74 & 0.73 & 0.82 \\
\hline & & 266 & GA & -16.0 & $-17.8 ;-14.2$ & & & & -0.2 & $-3.3 ; 2.9$ & & & & -7.0 & $-8.5 ;-5.4$ & & & \\
\hline & & 49 & $A A$ & -13.7 & $-18.0 ;-9.4$ & & & & 3.4 & $-3.8 ; 10.7$ & & & & -7.9 & $-11.5 ;-4.3$ & & & \\
\hline \multirow[t]{3}{*}{2} & rs3763497 & 284 & $\mathrm{CC}$ & -15.0 & $-16.7 ;-13.3$ & 0.14 & 0.25 & 0.62 & 0.8 & $-2.2 ; 3.8$ & 0.77 & 0.17 & 0.21 & -7.4 & $-8.9 ;-5.9$ & 0.80 & 0.64 & 0.76 \\
\hline & & 282 & $\mathrm{CT}$ & -17.4 & $-19.2 ;-15.7$ & & & & 1.1 & $-1.9 ; 4.2$ & & & & -7.9 & $-9.4 ;-6.3$ & & & \\
\hline & & 68 & TT & -14.0 & $-17.5 ;-10.5$ & & & & -3.6 & $-9.8 ; 2.6$ & & & & -6.8 & $-10.0 ;-3.7$ & & & \\
\hline \multirow[t]{3}{*}{2} & rs3793344 & 234 & $A A$ & -14.8 & $-16.7 ;-12.9$ & 0.19 & 0.32 & 0.89 & 1.0 & $-2.3 ; 4.3$ & 0.65 & 0.27 & 0.30 & -7.1 & $-8.8 ;-5.5$ & 0.71 & 0.55 & 0.78 \\
\hline & & 295 & $A G$ & -17.1 & $-18.8 ;-15.4$ & & & & 0.8 & $-2.1 ; 3.8$ & & & & -7.8 & $-9.3 ;-6.4$ & & & \\
\hline & & 114 & GG & -14.5 & $-17.3 ;-11.8$ & & & & -2.0 & $-6.8 ; 2.7$ & & & & -6.7 & $-9.1 ;-4.3$ & & & \\
\hline \multirow[t]{3}{*}{2} & rs9658194 & 422 & $\mathrm{CC}$ & -15.3 & $-16.8 ;-13.9$ & 0.08 & 0.79 & 0.97 & 0.7 & $-1.7 ; 3.2$ & 0.52 & 0.61 & 0.69 & -7.3 & $-8.5 ;-6.0$ & 0.77 & 0.63 & 0.62 \\
\hline & & 200 & $C A$ & -17.8 & $-19.9 ;-15.7$ & & & & -1.1 & $-4.7 ; 2.6$ & & & & -7.5 & $-9.3 ;-5.7$ & & & \\
\hline & & 20 & $A A$ & -15.2 & $-21.9 ;-8.6$ & & & & 3.1 & $-8.2 ; 14.4$ & & & & -8.8 & $-14.4 ;-3.1$ & & & \\
\hline \multirow[t]{2}{*}{2} & rs 4988515 & 546 & $G G$ & -16.1 & $-17.4 ;-14.9$ & 0.40 & & & 0.7 & $-1.5 ; 2.8$ & 0.55 & & & -7.7 & $-8.8 ;-6.6$ & 0.39 & & \\
\hline & & 63 & $\mathrm{GA} / \mathrm{AA}$ & -14.4 & $-18.1 ;-10.8$ & & & & -1.4 & $-7.8 ; 5.0$ & & & & -6.2 & $-9.4 ;-3.0$ & & & \\
\hline \multirow[t]{3}{*}{2} & rs 1908751 & 346 & $\mathrm{CC}$ & -15.8 & $-17.4 ;-14.2$ & 0.88 & 0.43 & 0.50 & 0.3 & $-2.5 ; 3.0$ & 0.91 & 0.94 & 0.93 & -7.6 & $-9.0 ;-6.3$ & 0.53 & 0.86 & 0.76 \\
\hline & & 249 & $\mathrm{CT}$ & -16.3 & $-18.2 ;-14.4$ & & & & 0.1 & $-3.1 ; 3.3$ & & & & -7.0 & $-8.6 ;-5.4$ & & & \\
\hline & & 45 & TT & -14.2 & $-18.6 ;-9.8$ & & & & -0.1 & $-7.6 ; 7.4$ & & & & -7.0 & $-10.8 ;-3.2$ & & & \\
\hline
\end{tabular}

Mean values and CIs of the non-dense area and percentage breast density were adjusted for BMI and change in BMI over menopause.

a $\mathrm{P}$-value for dominant mode of inheritance.

P-value for recessive mode of inheritance.

$\mathrm{SNP}=$ single nucleotide polymorphism; $\mathrm{CI}=$ confidence interval 